\title{
PENGARUH KEPEMIMPINAN, HUBUNGAN KERJA DAN LINGKUNGAN KERJA FISIK TERHADAP DISIPLIN KERJA KARYAWAN
}

\author{
I Wayan Sugiantara ${ }^{1}$ \\ I Komang Ardana ${ }^{2}$ \\ ${ }^{1}$ Fakultas Ekonomi dan Bisnis Universitas Udayana (Unud), Bali, Indonesia \\ email: almondsinside@yahoo.com
}

\begin{abstract}
ABSTRAK
Persaingan bisnis dibidang akomodasi pariwisata menyebabkan pimpinan dan karyawan perusahaan, khususnya tempat penginapan dituntut untuk selalu bertindak secara professional. Tujuan dari penelitian ini ialah (1) Untuk mengetahui gaya kepemimpinan, hubungan kerja dan lingkungan kerja fisik secara simultan berpengaruh signifikan terhadap disiplin kerja karyawan, (2) untuk mengetahui gaya kepemimpinan, hubungan kerja dan lingkungan kerja fisik secara parsial berpengaruh signifikan terhadap disiplin kerja karyawan, (3) untuk mengetahui gaya kepemimpinan, hubungan kerja dan lingkungan kerja fisik secara dominan berpengaruh signifikan terhadap disiplin kerja karyawan. Penelitian ini dilakukan di Alam kulkul Boutique Resort Kuta-Bali yang bergerak dibidang akomodasi pariwisata dengan menggunakan metode sensus (total sampling) dalam menentukan sampel sebanyak 65 responden, melalui teknik analisis regresi linier berganda.Hasil analisis membuktikan bahwa kepemimpinan, hubungan kerja dan lingkungan kerja fisik secara simultan berpengaruh positif dan signifikan terhadap disiplin kerja karyawan. Kepemimpinan, hubungan kerja dan lingkungan kerja fisik secara parsial berpengaruh positif dan signifikan terhadap disiplin kerja karyawan. Lingkungan kerja secara dominan berpengaruh positif dan signifikan terhadap disiplin kerja karyawan.

Kata kunci : kepemimpinan, hubungan kerja, lingkungan kerja fisik dan disiplin kerja
\end{abstract}

\section{ABSTRACT}

Business competition in the field of tourism accommodation causes corporate leaders and employees, especially lodging places, are required to always act professionally. The purpose of this study are (1) to determine the leadership style, work relationship and physical work environment simultaneously have a significant effect on employee work discipline, (2) to know the leadership style, work relationship and physical work environment partially have a significant effect on employee work discipline, (3) to find out the leadership style, work relationship and physical work environment dominantly have a significant influence on employee work discipline. This research was conducted in Alam Kulkul Boutique Resort Kuta-Bali which is engaged in tourism accommodation using census method (total sampling) in determining a sample of 65 respondents, through multiple linear regression analysis techniques. The results of the analysis prove that leadership, work relationships and physical work environment simultaneously have a positive and significant effect on employee work discipline. Leadership, work relations and physical work environment partially have a positive and significant effect on employee work discipline. The work environment has a dominant and significant positive effect on employee work discipline.

Keywords: leadership, work relationships, physical work environment and work discipline 
I Wayan Sugiantara, Pengaruh Kepemimpinan, Hubungan....

\section{PENDAHULUAN}

Persaingan dan perkembangan bisnis dunia usaha khususnya dibidang akomodasi pariwisata seperti penginapan di Bali ini dirasakan semakin maju dan semakin pesat yang membawa dampak pada persaingan yang semakin kompetitif (Mantra, 2008). Situasi seperti ini menyebabkan pimpinan dan karyawan perusahaan, khususnya tempat penginapan dituntut untuk selalu bertindak secara professional dan terorganisir dalam mencapai tujuan perusahaan (Valensia, 2015). Setiap perusahaan yang didirikan umumnya mempunyai tujuan untuk memaksimalkan nilai perusahaan bagi pemiliknya agar mendapatkan tingkat keuntungan yang maksimal dalam mempertahankan kelangsungan hidup perusahaan. Dapatlah dikemukakan bahwa faktor manusia atau tenaga kerja memegang peranan penting, sebab betapa pun majunya sesuatu teknologi, dalam prakteknya untuk menggerakan atau mengendalikan alat tersebut dibutuhkan tenaga manusia, dalam hal ini terutama karyawan yang mempunyai kemampuan, tanggung jawab, serta disiplin kerja tinggi yang harus dipertahankan (Fransiska, 2016).

Bali merupakan salah satu kawasan pariwisata di Indonesia yang saat ini mampu menampung jumlah wisatawan yang terus bertambah dari waktu ke waktu. Bali memiliki beragam tempat wisata yang terkenal sampai mancan negara, salah satu tempat wisata tersebut adalah di daerah Kuta Kabupaten Badung. Dimana Hotel Asana Agung Putra bertempat di daerah kuta dan merupakan salah satu pilihan untuk menginap bagi para wisatawan lokal maupun asing. Tenaga kerja atau karyawan merupakan sumber daya manusia yang sangat 
penting dalam suatu perusahaan, karena tanpa karyawan perusahaan tidak dapat berjalan dengan baik. Cholil dan Riani (dalam Mulyati, 2003) mengatakan bahwa karyawan adalah sebagai modal utama bagi perusahaan oleh sebab itu karyawan perlu dikelola agar tetap menjadi produktif akan tetapi dalam pengelolaannya bukanlah hal yang mudah, karena karyawan mempunyai pikiran, status, serta latar belakang yang berbeda. SDM senantiasa melekat pada setiap organisasi apapun sebagai faktor penentu keberadaan dan peranannya dalam memberikan konstribusi kearah pencapaian tujuan organisasi secara efektif dan efisien.

Bali merupakan salah satu daerah tujuan pariwisata di Indonesia yang memiliki daya tarik bagi wisatawan domestik maupun wisatawan mancangara. Sebagai daerah tujuan pariwisata tentunya Bali wajib menyediakan sarana dan prasana pendukung pariwisata sehingga hal tersebut mampu menarik minat para investor maupun pengusaha untuk mengembangkan usaha bisnis dibidang akomodasi pariwisata. Persaingan dan perkembangan bisnis dunia usaha khususnya dibidang akomodasi pariwisata seperti penginapan di Bali ini dirasakan semakin maju dan semakin pesat yang membawa dampak pada persaingan yang semakin kompetitif (Mantra, 2008).

Situasi seperti ini menyebabkan pimpinan dan karyawan perusahaan, khususnya tempat penginapan dituntut untuk selalu bertindak secara professional dan terorganisir dalam mencapai tujuan perusahaan (Muslim, 2008). Setiap perusahaan yang didirikan umumnya mempunyai tujuan untuk memaksimalkan nilai perusahaan bagi pemiliknya agar mendapatkan tingkat keuntungan yang maksimal dalam mempertahankan kelangsungan hidup perusahaan. Tety (2006) 
mengatakan tujuan ini akan tercapai dengan perkembangan kinerja sumber daya manusia yang lebih terampil melalui perencanaan, pengorganisasian, pengarahan, dan pengawasan yang baik sehingga perusahaan akan dapat berjalan sesuai dengan apa yang telah direncanakan.

Pentingnya kepuasan kerja pegawai dalam suatu organisasi dapat dilihat dari pegawai yang merasa puas dalam pekerjaanya cenderung memberikan respon positif terhadap organisasi, begitu pada sebaliknya pegawai yang tidak puas dalam pekerjaanya akan cenderung memberikan respon yang tidak baik terhadap pekerjaannya, maka dari itu kepuasan kerja pegawai harus menjadi perhatian utama manajemen dalam suatu organisasi (Afriani, 2013). Kepuasan kerja adalah sikap umum terhadap pekerjaan seseorang yang menunjukan perbedaan antara jumlah penghargaan yang ditrima pekerjaan jumlah yang mereka yakini seharusnya mereka terima (Robbins, 2003:78).

Bali yang ditetapkan sebagai pusat pariwisata di Indonesia bagian tengah merupakan daerah wisata yang tidak saja terkenal dengan keramah tamahan penduduknya, adat istiadatnya, alamnya yang indah, atraksi wisata serta mempunyai keaneka ragaman kebudayaan masing-masing daerah yang ada di Bali. Keadaan ini membuka peluang bagi industri pariwisata untuk lebih berkembang dan mampu menyediakan lapangan pekerjaan dan menyerap tenaga kerja serta mampu mendatangkan devisa bagi Negara. Kunjungan wisatawan ke Pulau Bali berdampak juga kepada sektor-sektor yang lain, dimana semakin berkembangnya wisata ini maka sektor-sektor yang berkaitan dengan pariwisata 
juga berkembang. Untuk lebih jelasnya jumlah wisatawan yang berkunjung ke Bali dapat kita lihat pada Tabel 1.

\section{Tabel 1}

Jumlah Kunjungan Wisatawan Mancanegara dan Wisatawan Domestik Datang Ke Bali

Tahun 2007 - 2012

\begin{tabular}{cccccccc}
\hline \multirow{2}{*}{$\begin{array}{c}\text { N } \\
\mathbf{0}\end{array}$} & Tahun & $\begin{array}{c}\text { Mancanegara } \\
\text { (Orang) }\end{array}$ & $\begin{array}{c}\text { Pertum. } \\
(\%)\end{array}$ & $\begin{array}{c}\text { Domestik } \\
\text { (Orang) }\end{array}$ & $\begin{array}{c}\text { Pertum. } \\
(\%)\end{array}$ & $\begin{array}{c}\text { Total } \\
\text { (Orang) }\end{array}$ & $\begin{array}{c}\text { Pertum. } \\
(\%)\end{array}$ \\
\hline 1 & 2007 & 1.458 .309 & - & 2.038 .186 & - & 3.496 .495 & - \\
2 & 2008 & 1.386 .309 & $(4,93)$ & 2.408 .509 & 18,2 & 3.794 .958 & 8,6 \\
3 & 2009 & 1.260 .317 & $(9,09)$ & 2.474 .787 & 2.76 & 3.735 .104 & $(1,6)$ \\
4 & 2010 & 1.664 .854 & 32,1 & 2.484 .644 & 0,39 & 4.149 .498 & 11,09 \\
5 & 2011 & 1.968 .892 & 18,3 & 1.989 .794 & 16,7 & 4.867 .686 & 17,4 \\
6 & 2012 & 2.229 .945 & 13,3 & 3.521 .135 & 0,22 & 5.751 .080 & 18,2 \\
\multicolumn{2}{l}{ Total } & $\mathbf{9 . 9 6 8 . 7 6 6}$ & $\mathbf{4 9 , 8 6}$ & $\mathbf{1 5 . 6 2 6 . 0 0 5}$ & $\mathbf{3 8 , 2 7}$ & $\mathbf{2 5 . 7 3 4 . 8 2 1}$ & $\mathbf{5 3 , 9}$ \\
\multicolumn{2}{l}{ Rata-rata } & $\mathbf{1 . 6 6 1 . 4 6 1}$ & $\mathbf{8 , 2 8}$ & $\mathbf{2 . 6 3 7 . 6 7 5}$ & $\mathbf{6 , 3 7 8 3}$ & $\mathbf{4 . 2 8 9 . 1 3 6}$ & $\mathbf{8 , 6}$ \\
\hline
\end{tabular}

Sumber : Dinas Pariwisata Bali, 2013

Tabel 1. dapat dilihat jumlah kunjungan wisatawan ke Bali tertinggi yaitu pada tahun 2012 sebanyak 5.751 .080 orang pertahun dan terendah pada tahun 2007 dengan total kunjugan sebanyak 3.496.495. Sedangkan penurunan terbanyak terjadi pada tahun 2009 yaitu dengan pertumbuhan sebesar $(1,6)$ persen atau mengalami penurunan sebesar 7 persen dari tahun 2008 dan kembali mengalami pertumbuhan pada tahun tahun berikutnya dengan pertumbuhan tertinggi pada tahun 2010 sebesar 11,09 persen atau mengalami peningkatan sebesar 9,49 persen dari tahun 2009. Rata-rata peningkatan jumlah kunjungan wisatawan ke Bali pertahun sebanyak 8,6 persen.

Peningkatan jumlah wisatawan yang datang ke Bali maka pihak-pihak yang bergelut di dunia usaha, misalnya pihak yang menjual jasa seperti tempat wisata, hotel, restoran, dan industri lain tidak mau membuang kesempatan tersebut. Sehingga terjadi persaingan yang ketat dalam memperoleh wisatawan, hal ini bisa 
I Wayan Sugiantara, Pengaruh Kepemimpinan, Hubungan....

dibuktikan dengan maraknya promosi-promosi yang dilakukan antar perusahaan yang bergelut dalam usaha industri pariwisata. Kondisi ini menyebabkan banyak perusahaan yang tidak bertahan lama karena persaingan yang semakin ketat antar perusahaan-perusahaan yang menjalankan usaha yang sejenis.

Kondisi perekonomian seperti ini, menuntut setiap perusahaan untuk terus bertahan dan berhasil dalam mencapai tujuannya serta dapat menjalankan usaha atau organisasi dengan efektif dan efisien (Widyastuti, 2006). Sebagai suatu perusahaan yang bergerak dibidang industri pariwisata tentunya menginginkan agar usahanya berkembang secara berkesinambungan dan memperoleh laba. Keberhasilan tercapainya tujuan suatu perusahaan, baik perusahaan swasta maupun perusahaan milik negara atau sektor publik sangat tergantung pada kemampuan dan keahlian pimpinan dalam melaksanakan fungsi perusahaan seperti pemasaran, produksi, keuangan, administrasi dan personalia (Nola, 2008). Fungsi perusahaan satu sama lainnya mempunyai hubungan yang saling keterkaitan. Namun demikian fungsi personalia mempunyai peran yang sangat strategis dari fungsi - fungsi perusahaan lainnya.

Disiplin yang baik mencerminkan besarnya rasa tanggung jawab seseorang terhadap tugas-tugas yang diberikan kepadanya (Heru, 2018). Hal ini mendorong gairah dan semangat kerja serta terwujudnya tujuan perusahaan, karyawan, dan masyarakat. Marie (2010) dalam penelitiannya menyatakan menerapkan disiplin kerja yang positif dapat menciptakan lingkungan kerja yang baik bagi karyawan. Lain halnya dengan Bangun (2014) dalam penelitiannya menyatakan kebijakan 
disiplin yang diterapkan perusahaan bertujuan untuk meningkatkan gairah kerja dan semangat kerja karyawan dalam menyelesaikan pekerjaannya.

Alam Kulkul Boutique Resort Kuta-Bali adalah salah satu Villa yang bergerak dibidang pariwisata di Bali. Perusahaan ini memiliki visi menjadi salah satu villa yang terbaik dan terdepan dalam dunia pariwisata. Sedangkan misinya ingin lebih meningkatkan produktivitas, efesiensi dan efektif dalam bidangnya. Untuk dapat mengantisipasi persaingan, perusahaan hendaknya memberikan pelayanan yang baik yang ditawarkan perusahaan. Dalam penyelesaian pekerjaannya memerlukan ketelitian kerja dari para karyawan, maka haruslah didukung dengan memiliki karyawan yang mempunyai kinerja yang baik dan tingkat disiplin yang tinggi dalam mengerjakan segala tugas-tugasnya sehingga tujuan perusahaan dapat tercapai. Untuk memelihara dan mewujudkan disiplin yang baik, ada banyak faktor yang berpengaruh yaitu: kepemimpinan, hubungan kerja, dan lingkungan kerja seperti yang diungkapkan oleh Susilo (2007:169).

Kepemimpinan adalah salah satu faktor yang berperan penting terhadap maju mundurnya suatu organisasi. Deni (2012) menyatakan kepemimpinan yang baik akan membawa iklim perusahaan yang baik, dimana karyawan akan memberikan hasil kerja yang maksimal yang ditunjukkan dalam sikap positif terhadap pekerjaan dan segala sesuatu yang dihadapi ataupun yang ditugaskan kepadanya. Alam kulkul Boutique Resort Kuta-Bali sedang mengalami masalah dalam kepemimpinan. Berdasarkan informasi yang diperoleh dari karyawan, dapat diketahui bahwa pemimpin yang ada diperusahaan ini tidak dapat melakukan fungsi kepemimpinannya secara efektif. Pemimpin cenderung arogan, tidak 
I Wayan Sugiantara, Pengaruh Kepemimpinan, Hubungan....

menghargai karyawan sebagai bagian dari perusahaan, dan tidak mau menerima saran-saran dari karyawan, sehingga para karyawan merasa tertekan dan cenderung memendam niatnya untuk mengeluarkan pendapat dan berkomunikasi dengan pemimpin. Ketidak efektifan kepemimpinan ini memiliki efek bagi karyawan, diantaranya terjadi kejenuhan dalam aktivitas kerja, adanya tingkat absensi tinggi, yang berujung pada menurunnya tingkat disiplin kerja karyawan (Jhon, 2011).

Selain masalah kepemimpinan, hubungan kerja juga dapat menentukan tingkat disiplin kerja karyawan di dalam suatu perusahaan, Hubungan kerja merupakan hubungan timbal balik antara atasan dengan bawahan (Fazriyas dan Elwamendri, 2010). Dalam hal ini antara pimpinan dan karyawan tentunya harus ada timbal balik dimana karyawan membantu pekerjaan pimpinan dan mendapatkan gaji dengan demikian karyawan dapat memenuhi kebutuhannya dan pimpinan dapat menjalankan perusahaan dengan baik, (Widyastuti, 2006). Pemaparan di atas menjelaskan bahwa masalah hubungan kerja pada Alam kulkul Boutique Resort Kuta-Bali menjadi suatu hal penting, karena hubungan kerja merupakan suatu indikator yang berpengaruh terhadap disiplin kerja karyawan.

Selain masalah hubungan kerja, lingkungan kerja fisik juga berperan penting dalam menentukan tingkat disiplin kerja karyawan di dalam suatu perusahaan, lingkungan kerja adalah segala sesuatu gejala fisik yang ada disekitar pekerja yang dapat mempengaruhi dirinya dalam menjalankan tugas-tugas yang dibebankan misalnya, pewarnaan, kebersihan, pertukaran udara, ruang gerak, keamanan dan kebisingan (Nitisemito, 2007:183). Lingkungan kerja fisik pada 
Alam kulkul Boutique Resort Kuta-Bali secara umum masih kurang nyaman untuk karyawan seperti penerangan berupa lampu atau sinar matahari kurang maksimal, suhu udara dalam ruangan kerja tidak teratur karena $\mathrm{AC}$ sering rusak, ruang kerjanya sempit, kebersihan kantor belum terjamin, dan masih banyak barang yang disimpan disembarang tempat karena gudangnya sangat sempit sehingga mengganggu ruang gerak karyawan. Lingkungan kerja fisik yang mendukung membuat karyawan merasa betah untuk melaksanakan kewajibannya dan juga sebagai penunjang untuk meningkatkan kinerjanya (Dewi, 2010).

Penegakan disiplin adalah salah satu faktor yang cukup besar mempengaruhi disiplin kerja karyawan, tetapi Alam kulkul Boutique Resort KutaBali penegakan disiplin belum begitu banyak diperhatikan. Tony (2004) dalam penelitiannya menyatakan mengembangkan prosedur pendisiplinan yang baik di dalam suatu perusahaan akan mendukung pengoperasian disiplin yang postif bagi karyawan. Berdasarkan urain di atas maka penelitian tentang pengaruh kepemimpinan, hubungan kerja, dan lingkungan kerja fisik penting untuk dilakukan karena tingkat kedisiplinan kerja karyawan pada Alam kulkul Boutique Resort Kuta-Bali mempunyai tingkat disiplin yang rendah.

Melalui pemaparan masalah yang telah dijabarkan, didukung dengan karya ilmiah dan teori tujuan dari karya ilmiah ini yang hendak dicapai 1) Apakah kepemimpinan, hubungan kerja, dan lingkungan kerja fisik secara parsial berpengaruh positif dan signifikan terhadap disiplin kerja karyawan pada Alam kulkul Boutique Resort Kuta-Bali, 2) Di antara kepemimpinan, hubungan kerja, 
dan lingkungan kerja fisik manakah yang berpengaruh dominan terhadap disiplin kerja karyawan pada Alam kulkul Boutique Resort Kuta-Bali.

Menurut Gouzali (2007:111) disiplin adalah sikap dan prilaku seorang karyawan yang diwujudkan dalam bentuk kesediaan seorang karyawan dengan penuh kesadaran, dan ketulus ikhlasan atau dengan paksaan untuk mematuhi dan melaksanakan seluruh peraturan dan kebijaksanaan perusahaan didalam melaksanakan tugas dan tanggung jawab sebagai upaya memberi sumbangan semaksimal mungkin dalam pencapaian tujuan perusahaan, sedangkan menurut Hasibuan (2007:212 ) disiplin kerja adalah kesadaran dan kesediaan seseorang mentaati semua peraturan perusahaan dan norma-norma sosial yang berlaku lain halnya dengan Nitisemito (2007:118 ) disiplin kerja diartikan sebagai suatu sikap, tingkah laku, dan perbuatan yang sesuai dengan peraturan perusahaan baik yang tertulis maupun tidak tertulis.

Tony (2004) mengemukakan disiplin kerja memiliki arti yang sangat penting bagi kelangsungan hidup perusahaan, dengan tingkat disiplin kerja yang sangat tinggi, perusahaan dapat mencapai sasaran dan tujuan yang diinginkan dengan efektif dan efisien, ebaliknya apabila perusahaan dalam kondisi dimana tingkat disiplinnya rendah, perusahaan akan mengalami hambatan dalam mencapai sasaran dan tujuan yang telah ditetapkan, karena pembinaan disiplin karyawan yang baik akan membangun semangat kerja dan meningkatkan mutu prestasi kerja karyawan di dalam upaya memberi sumbangan akan tercapainya kinerja perusahaan, (Gouzali, 2007:114). Disiplin merupakan modal yang 
diperlukan dalam suatu perusahaan, oleh karena itu seluruh elemen perusahaan wajib melaksanakannya.

Apfia (2017) menyatakan disiplin merupakan modal yang diperlukan dalam suatu organisasi atau perusahaan. Untuk itu seluruh elemen perusahaan wajib melaksanakannya. Menurut Gouzali (2007:170), disiplin yang diharapkan dari karyawan pada dasarnya ada dua, yaitu 1) Mematuhi segala peraturan yang berlaku, 2) Menjauhi segala larangan yang berlaku dalam perusahaan.

Disamping perusahaan menuntut karyawannya untuk berdisiplin, perusahaan pun dituntut oleh karyawan untuk berdisiplin. Disiplin yang harus diperhatikan perusahaan yaitu 1) Tiap suatu tindakan pada karyawan harus mempunyai dasar yang sudah diketahui karyawan, 2) Taat asas (konsisten) dan selalu menepati janji.

Menurut Gouzali (2007:287) indikasi-indikasi turunnya disiplin kerja karyawan adalah tingginya angka kemangkiran (absensi) karyawan. Sering terlambatnya karyawan masuk kantor dan pulang lebih cepat dari jam yang sudah ditentukan. Menurunnya semangat dan gairah kerja.Tidak tercapainya target perusahaan yang sudah diprogramkan. Merosotnya produktivitas dan hasil pekerjaan. Terjadinya pemborosan dalam pemakaian material dan peralatan milik perusahaan. Adanya kecenderungan bangkrutnya perusahaan secara keseluruhan. Faktor-Faktor Yang Mempengaruhi Disiplin Kerja

Menurut Handoko (2007:120) faktor-faktor penyebab tumbuhnya disiplin kerja adalah kesadaran karyawan, komunikasi yang sehat, dan kepemimpinan, sedangkan menurut Martoyo (2007:165) bahwa faktor-faktor yang mempengaruhi 
disiplin kerja adalah motivasi, pengalaman kerja, pendidikan dan pelatihan, kepemimpinan, kesejahteraan, kompensasi, dan penegakan disiplin. Lain halnya dengan pendapat.

Hasibuan (2007:194) menyatakan bahwa faktor yang mempengaruhi disiplin kerja adalah tujuan dan kemampuan, teladan kepemimpinan, balas jasa, keadilan, sanksi hukum, ketegasan dan hubungan kemanusiaan. Dari uraian dari beberapa pendapat tersebut dapat ditarik kesimpulan bahwa variabel yang berpengaruh terhadap disiplin kerja adalah motivasi, pengalaman kerja, pendidikan dan pelatihan, kepemimpinan, dan penegakan disiplin.

Kepemimpinan

Hasibuan (2007 : 169) menyatakan bahwa pemimpin adalah seseorang yang mempergunakan wewenang kepemimpinannya, mengarahkan bawahannya untuk mengerjakan sebagian pekerjaannya dalam pencapaian tujuan perusahaan. Sedangkan menurut Nitisemito (2007 : 189), kepemimpinan adalah suatu proses penggunaan pengaruh positif terhadap orang lain untuh melakukan usaha lebih banyak dalam sejumlah tugas atau mengubah perilakunya. Kepemimpinan diartikan juga suatu inisiatif untuk bertindak yang menghasilkan suatu pola yang konsisten dalam rangka mencari jalan pemecahan dari suatu persoalan bersama (Stephen, 2013). Lebih jauh lagi Tohardi (2008 : 5) merumuskan bahwa kepemimpinan itu adalah aktivitas untuk mempengaruhi orang-orang supaya diarahkan mencapai tujuan organisasi.

Adapun indikator-indikator yang di ukur dari kepemimpinan ini adalah (Deni, 2012), tingkat kepercayaan bawahan terhadap pepimpin. Keyakinan 
bawahan terhadap pemimpin. Rasa hormat bawahan terhadap pemimpin. Kekuasaan memecat karyawan. Kekuatan menaikkan pangkat karyawan.

Hubungan kerja yaitu hubungan antara pekerja dan pengusaha, terjadi setelah diadakan perjanjian oleh pekerja dengan pengusaha, di mana pekerja menyatakan kesanggupannya untuk bekerja pada pengusaha dengan menerima upah dan di mana pengusaha menyatakan kesanggupannya untuk mempekerjakan pekerja dengan membayar upah (Manulang, 2006:130).

Adapun indikator-indikator dari hubungan kerja ini adalah sebagai berikut (Muhaimin, 2004), komunikasi, kerjasama, saling menghargai dan pemahaman kerja. Manullang, (2006:12) menyatakan bahwa lingkungan kerja fisik adalah kondisi-kondisi pekerjaan yang menyenangkan terlebih lagi semasa jam kerja akan memperbaiki moral pegawai dan kesungguhan dalam bekerja. Peralatanperalatan yang baik dan perlindungan terhadap mara bahaya, vetilasi yang baik, penerangan yang cukup dan kebersihan bukan saja menambah kegairahan kerja tetapi juga akan meningkatkan disiplin kerja karyawan. Tohardi (2008:136) Menyatakan bahwa lingkungan kerja fisik walaupun diyakini bukanlah faktor utama dalam meningkatkan disiplin kerja namun lingkungan kerja fisik merupakan variabel yang perlu diperhitungkan oleh pakar manajemen. Handoko (2007:22) menyatakan bahwa lingkungan kerja adalah gejala fisik dan non fisik dari dalam organisasi yang dilayani karyawan yang dapat mempengaruhi karyawan dalam bekerja pada lingkunganya.

Berdasarkan pengertian tersebut, maka dapat disimpulkan bahwa lingkungan kerja fisik adalah keseluruhan dari faktor intern dan ekstern yang ada 
I Wayan Sugiantara, Pengaruh Kepemimpinan, Hubungan....

di sekitar tempat kerja setiap karyawan, dalam hal ini adalah berupa tempat fisik terdiri dari meja, kursi, serta peralatan kerja lainnya yang dapat mempengaruhi karyawan di dalam melaksanakan tugas dan pekerjaanya sehari-hari. Pihak manajemen atau pimpinan yang ingin menciptakan lingkungan kerja yang menyenangkan, maka perlu memberi perhatian pada penataan ruang kerja secara fisik seperti, peralatan kerja, penerangan, kebisingan, dan kenyamanan sehingga nantinya akan mampu meningkatkan kedisiplinan kerja karyawan karena karyawan merasa betah bekerja di ruangannya.

Tohardi, (2008:137) menyatakan bahwa yang termasuk ke dalam lingkungan kerja fisik adalah ruangan, penerangan, gangguan dalam ruangan, keadaan udara, warna, kebersihan dan suara dalam ruang kerja. Penjelasan dari faktor-faktor lingkungan kerja fisik adalah ruangan atau tempat bekerja harus didesain sedemikian rupa, jangan sampai ruangan memberikan kesan tidak nyaman, kumuh, dan berantakan. Penerangan yang baik dapat memberikan kepuasan kerja yang nantinya akan mampu meningkatkan disiplin kerja karyawan, dengan penerangan yang baik akan memudahkan karyawan dalam melakukan aktivitasnya. Bunyi ribut dapat mengganggu konsentrasi dalam bekerja. Untuk itu suara-suara bising harus diredam, karena hal tersebut akan menyebabkan turunya konsentrasi dan berdampak kepada stress karyawan yang tentunya akan dapat menurunkan tingkat disiplin karyawan. Suhu udara atau temperatur ruang kerja karyawan merupakan salah satu faktor yang mempengaruhi kondisi kerja karyawan dalam suatu perusahaan. Suhu udara yang terlalu panas atau lembab akan menurunkan semangat kerja karyawan, sehingga kesalahan-kesalahan yang 
dibuat akan semakin bertambah dan itu berarti juga akan merugikan perusahaan. Penggunaan warna dapat dimasukan sebagai faktor lingkungan kerja fisik yang dapat memberikan pengaruh yang besar terhadap perasaan dan sifat. Pewarnaan ini meliputi: element dinding, langit-langit ruangan, peralatan kerja dan lain-lain. Kebersihan merupakan syarat guna menjaga kesehatan, dan pelaksanaanya harus dilakukan secara kontinyu. Dalam setiap perusahaan hendaknya selalu menjaga kebersihan lingkungan kerja. Bunyi atau suara bising dalam ruang kerja dapat menganggu ketenangan kerja, merusak pendengaran, sehingga akan mengganggu konsentrasi kerja yang dapat menimbulkan kesalahan dan kerusakan dalam bekerja.

Skema kerangka pemikiran ini menjelaskan bahwa kepemimpinan, hubungan kerja dan lingkungan kerja fisik dengan disiplin kerja karyawan yang telah diberikan untuk perusahaan. Untuk lebih jelasnya kerangka pemikiran dapat dilihat sebagai berikut.

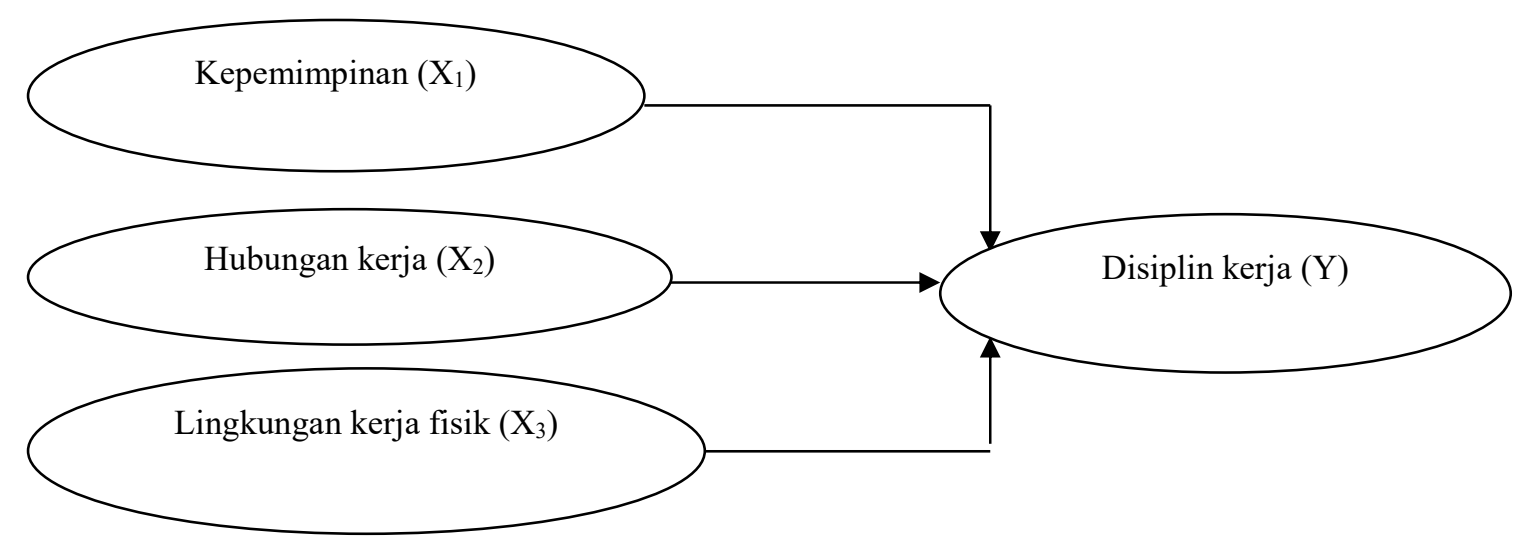

Gambar 1. Kerangka Pemikiran 
Penelitian sebelumnya telah membuktikan bahwa disiplin kerja dapat dipengaruhi berbagai variabel dimana diantaranya termasuk kepemimpinan, hubungan kerja dan lingkungan kerja fisik. Salah satunya Deni (2012) mengatakan bahwa kepemimpinan sebagian dari yang mempengaruhi disiplin kerja. Muhaimin (2004) mengatakan hubungan kerja berpengaruh simultan terhadap kedisiplinan karyawan dalam perusahaan. Lingkungan kerja fisik mempunyai pengaruh simultan dengan disiplin kerja pegawai (Rizki, 2009). Berdasarkan pemahaman tersebut dapat dirumuskan hipotesis pertama sebagai berikut.

$\mathrm{H}_{1}$ : Kepemimpinan, Hubungan kerja dan lingkungan kerja secara simultan mempengaruhi disiplin kerja karyawan.

Rifka et al. (2017) menyatakan kepemimpinan mempengaruhi kondisi dari karyawan yang berdampak terhadap disiplin kerja karyawan. Jhon (2011) dalam penelitiannya mengemukakan kepemimpinan memiliki pengaruh positif terhadap disiplin karyawan. Berdasarkan pemahaman tersebut dapat dirumuskan hipotesis kedua sebagai berikut.

$\mathrm{H}_{2}$ : Kepemimpinan berpengaruh positif dan signifikan terhadap disiplin kerja karyawan.

Hubungan kerja merupakan dasar untuk mencapai disiplin kerja karyawan (Fazriyas dan Elwamendri, 2010). Cevat et al. (2012) mengatakan bahwa hubungan kerja berpengaruh signifikan terhadap disiplin kerja pegawai. Berdasarkan pemahaman tersebut dapat dirumuskan hipotesis ketiga sebagai berikut.

$\mathrm{H}_{3}$ : Hubungan kerja berpengaruh positif dan signifikan terhadap disiplin kerja karyawan. 
Penelitian Wibowo (2007) menyimpulkan bahwa lingkungan kerja fisik merupakan salah satu variabel yang meningkatkan disiplin kerja karyawan. Lingkungan kerja fisik memiliki pengaruh secara parsial terhadap disiplin kerja pegawai (Dewi, 2010). Berdasarkan pemahaman tersebut dapat dirumuskan hipotesis keempat sebagai berikut.

$\mathrm{H}_{4}$ : Lingkungan kerja fisik berpengaruh positif dan signifikan terhadap disiplin kerja karyawan.

\section{METODE PENELITIAN}

Karya ilmiah ini menggunakan metode asosiatif yang bertujuan untuk mengetahui pengaruh ataupun juga hubungan antara dua variabel atau lebih (Sugiyono, 2013:56). Penelitian ini dilakukan pada Alam kulkul Boutique Resort Kuta-Bali yang berlokasi di jalan raya pantai Kuta-Bali. Adapun alasan yang melatarbelakangi peneliti melakukan penelitian pada Alam kulkul Boutique Resort Kuta-Bali yang merupakan usaha yang bergerak di bidang akomodasi pariwisata (jasa penginapan).

Obyek penelitian adalah suatu hal atau apa saja yang menjadi perhatian dan apa saja yang diteliti (kamus bahasa Indonesia, 2008). Sebagai obyek dalam penelitian adalah pengaruh kepemimpinan, hubungan kerja dan lingkungan kerja fisik terhadap disiplin kerja karyawan pada Alam kulkul Boutique Resort KutaBali. Variabel bebas adalah kepemimpinan $\left(\mathrm{X}_{1}\right)$, hubungan kerja $\left(\mathrm{X}_{2}\right)$, lingkungan kerja fisik $\left(\mathrm{X}_{3}\right)$ dan variabel terikat adalah disiplin kerja karyawan $(\mathrm{Y})$.

Jenis data kuantitatif dan kualitatif yang dipergunakan seperti data jumlah karyawan, jawaban responden terhadap kuisioner dan seperti sejarah perusahaan, 
struktur organisasi dan aktivitas perusahaan. Sumber data primer dan sekunder yang dipergunakan seperti observasi dan pemberian kuesioner kepada responden dan sejarah berdirinya perusahaan, struktur organisasi perusahaan, dan jumlah karyawan.

Sampel adalah karyawan Alam kulkul Boutique Resort Kuta-Bali sebanyak 65 orang, yang menjadi sampel dalam penelitian ini adalah keseluruhan dari populasi yaitu sebanyak 65 orang. Data yang dikumpulkan dalam penelitian ini menggunakan metode wawancara, pustaka dan kuesioner yang diberikan kepada responden yang telah dipilih.

Uji validitas menyatakan sebuah instrumen dikatakan valid jika item yang mempunyai korelasi positif dengan kriterum (skor total) serta korelasi tinggi menunjukkan bahwa item tersebut mempunyai validitas yang tinggi pula. Syarat minimum untuk dianggap memenuhi syarat adalah kalau $r=0,3$. Uji reabilitas ditunjukkan dengan angka indeks yang konsistensi suatu alat ukur dalam mengukur gejala yang sama. Uji reabilitas mampu menunjukan sejauh mana instrument dapat dipercaya dan diharapkan. Nilai suatu instrumen dikatakan reliabel bila nilai Alpha Cronbach $\geq 0,6$.

Karena dalam penelitian ini menggunakan statistik parametrik dengan model regresi berganda, maka sebelumnya perlu dilakukan uji asumsi klasik yang meliputi: Uji Normalitas Uji normalitas bertujuan untuk menguji apakah suatu data berdistribusi normal atau tidak, Uji Multikolonieritas, uji ini bertujuan untuk menguji apakah dalam model regresi ditemukan adanya kolerasi antara variabelvariabel bebas dan Uji heteroskedastisitas untuk menguji apakah dalam model 
regresi terjadi ketidaksamaan varians dari residual satu ke pengamatan yang lain tetap maka disebut homokedasitas jika berbeda disebut heteroskedastisitas.

Untuk menguji ketepatan model regresi pengaruh variabel bebas kepemimpinan $\left(\mathrm{X}_{1}\right)$, hubungan kerja $\left(\mathrm{X}_{2}\right)$, lingkungan kerja fisik $\left(\mathrm{X}_{3}\right)$ secara serempak terhadap variabel terikat disiplin kerja karyawan $(\mathrm{Y})$. Uji hipotesis (ttest) bertujuan untuk menguji signifikansi pengaruh variabel kepemimpinan $\left(\mathrm{X}_{1}\right)$, hubungan kerja $\left(\mathrm{X}_{2}\right)$, lingkungan kerja fisik $\left(\mathrm{X}_{3}\right)$ secara parsial terhadap variabel terikat disiplin kerja karyawan (Y).

Analisis Standardized Coefficients Beta bertujuan untuk menjawab hipotesis ketiga yaitu menentukan variabel bebas yang berpengaruh dominan terhadap variabel terikat. Dalam hal ini variabel bebas adalah kepemimpinan $\left(\mathrm{X}_{1}\right)$, hubungan kerja $\left(\mathrm{X}_{2}\right)$, lingkungan kerja fisik $\left(\mathrm{X}_{3}\right)$ sedangkan variabel terikat adalah disiplin kerja karyawan (Y). Standardized Coefficients Beta diperoleh dari hasil analisis pengolahan data melalui program SPSS (Ghozali, 2007:88).

\section{HASIL DAN PEMBAHASAN}

Uji validitas menyatakan sebuah instrumen dikatakan valid jika item yang mempunyai korelasi positif dengan kriterum (skor total) serta korelasi tinggi menunjukkan bahwa item tersebut mempunyai validitas yang tinggi pula. Syarat minimum untuk dianggap memenuhi syarat adalah kalau $r=0,3$. Hasil analisis uji validitas di tunjukkan pada Tabel 2.

Tabel 2 diketahui bahwa masih-masing indikator variabel memiliki nilai person correlation lebih besar dari 0,30, maka ini berarti indikator/pertanyaan 
I Wayan Sugiantara, Pengaruh Kepemimpinan, Hubungan....

yang digunakan layak digunakan untuk mengukur apa yang seharusnya diukur, dan dapat mengungkap data dari variabel yang diteliti secara tepat.

Tabel 2

Rangkuman Hasil Uji Validitas

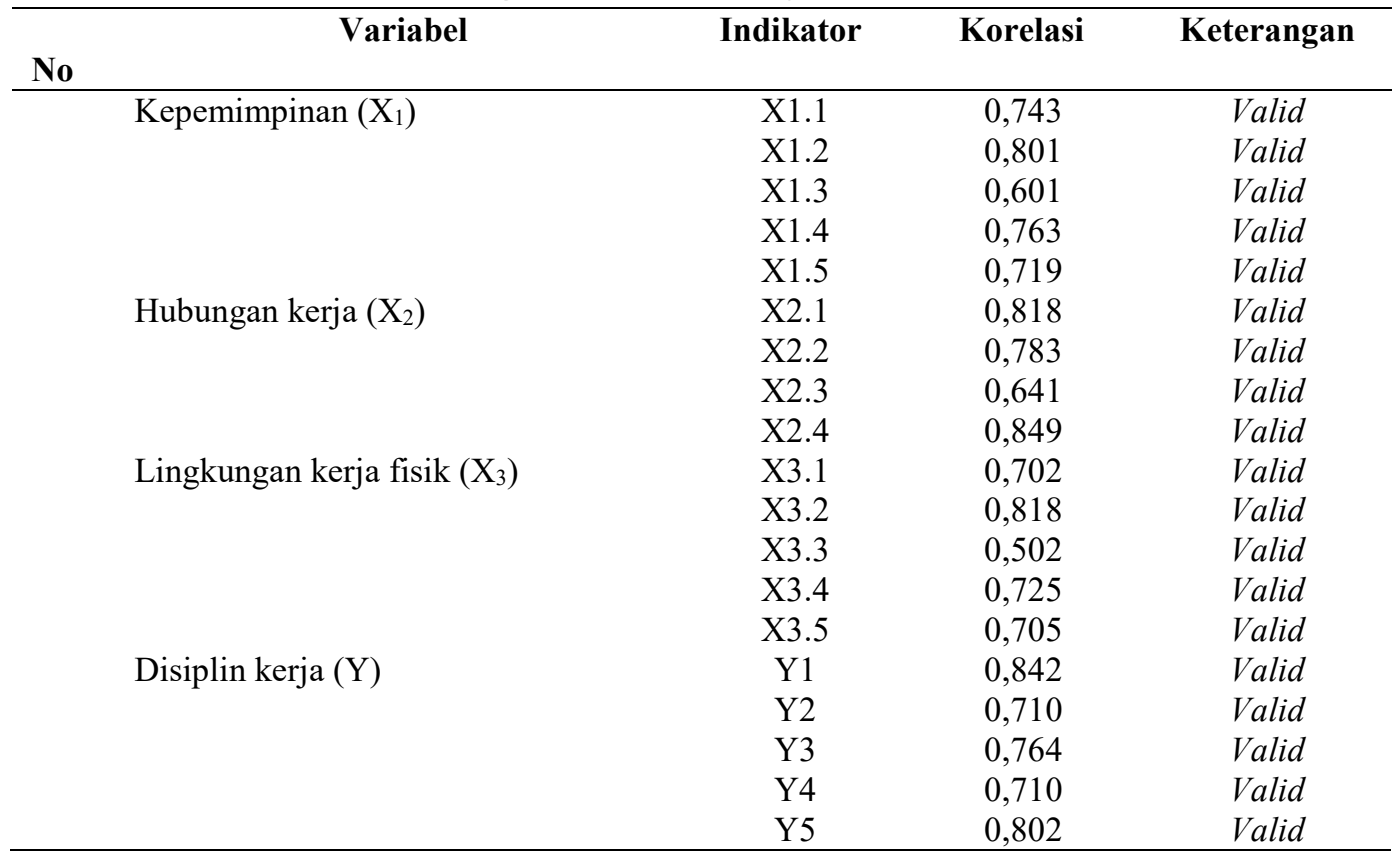

Sumber: data diolah, 2018

Tabel 3

Hasil Uji Reliabilitas

\begin{tabular}{llcc}
\hline Variabel & Cronbch's Alpha & Keterangan \\
\hline No & Kepemimpinan & 0,774 & Reliabel \\
Hubungan kerja & 0,779 & Reliabel \\
Lingkungan kerja fisik & 0,805 & Reliabel \\
Disiplin kerja & 0,822 & Reliabel \\
\hline
\end{tabular}

Sumber : data diolah, 2018

Tabel 3 diketahui bahwa nilai Cronbach's Alpha untuk masing-masing variabel $>0,6$, ini berarti alat ukur tersebut akan memberikan hasil yang konsisten apabila alat ukur tesebut digunakan kembali untuk meneliti obyek yang sama.

Hasil analisis regresi linear berganda bertujuan untuk mengetahui pegaruh kepemimpinan, hubungan kerja, lingkungan kerja fisik terhadap disiplin kerja karyawa yang dapat dilihat pada Tabel 4 berikut ini. 
Tabel 4

Rangkuman Hasil Analisis Regresi Linear Berganda

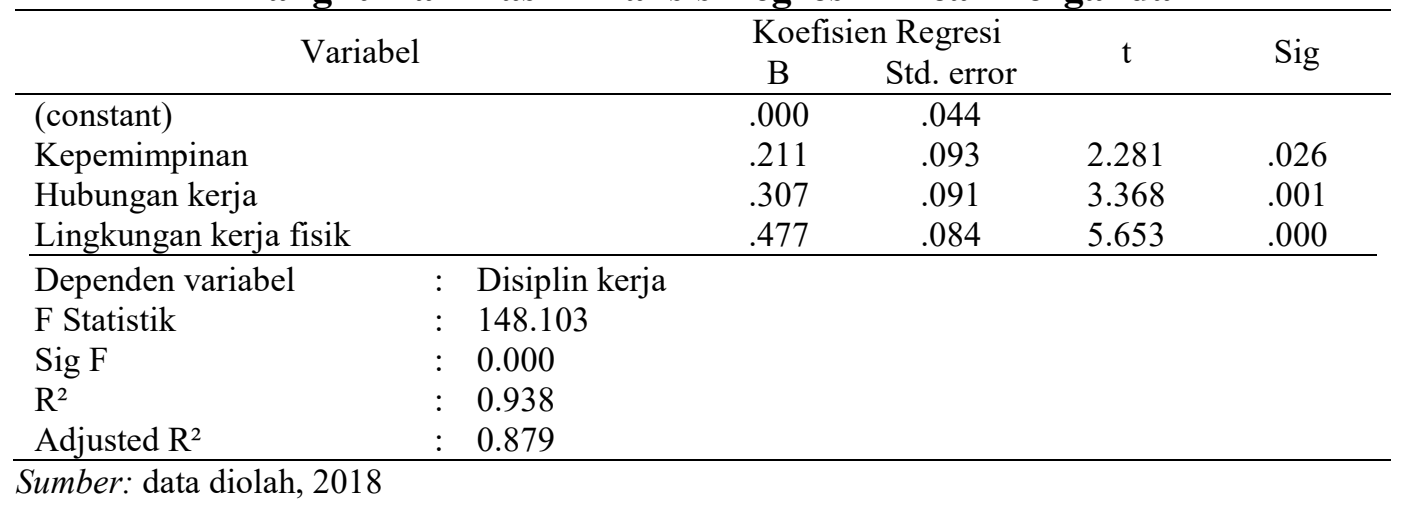

Berdasarkan Tabel 4 dapat ditulis persamaan regresi linear berganda sebagai berikut.

$$
Y=0,000+0,211 X_{1}+0,307 X_{2}+0,477 X_{3}
$$

Dimana :

$\mathrm{Y}=$ Disiplin kerja

$\mathrm{X}_{1}=$ Kepemimpinan

$\mathrm{X}_{2}=$ Hubungan kerja

$\mathrm{X}_{3}=$ Lingkungan kerja fisik

$\mathrm{R}^{2}=$ Koefisien determinasi

Pengujian Ketepatan Model Regresi (f-tes) ini menunjukkan hasil perhitungan regresi linear berganda yang dirangkum pada lampiran 6 dapat diketahui bahwa $F_{\text {hitung }}=148.103$ dan nilai $F_{\text {tabel }}$ dengan tingkat keyakinan 95\% dan $\alpha=0,05 ;$ df $=(\mathrm{k}-1):(\mathrm{n}-\mathrm{k})=(3: 61)$ adalah sebesar 2,76 . Oleh karena $\mathrm{F}_{\text {hitung }}$ (148.103) lebih besar dari $\mathrm{F}_{\text {tabel }}(2,76)$ dengan nilai signifikansi $0,000<0,05$ maka dapat disimpulkan kepemimpinan, hubungan kerja, lingkungan kerja fisik berpengaruh signifikan secara simultan terhadap disiplin kerja karyawan Alam Kulkul Boutique Resort.

Uji normalitas akan ditampilkan pada Tabel 5 hasil yang didapatkan dengan menggunakan uji Kolmogorov-Smirnov dengan signifikansi lebih besar dari 0,05 
yaitu 0,966 maka dapat disimpulkan bahwa model regresi terdistribusi secara normal.

Tabel 5

Hasil Uji Kolmogorov-Smirnov

\begin{tabular}{llr}
\hline & & $\begin{array}{c}\text { Unstandardized } \\
\text { Residual }\end{array}$ \\
\hline $\mathrm{N}$ & & 65 \\
Normal Parameters(a,b) & Mean & .0000000 \\
& Std, Deviation & .34744518 \\
Most Extreme Differences & Absolute & .051 \\
& Positive & .041 \\
Kolmogorov-Smirnov Z & Negative & -.051 \\
Asymp. Sig. (2-tailed) & & .410 \\
\hline
\end{tabular}

Sumber: data diolah, 2018

Berdasarkan hasil pengujian multikolinearitas diketahui nilai VIF (Varian Inflatation Factor) tidak lebih dari 10 dan mempunyai angka tolerance tidak kurang dari 0,1 , maka ini berarti dalam model regresi tidak terjadi multikolinearitas yang dapat dilihat pada Tabel 6 berikut.

Tabel 6

Hasil Uji Multikolinearitas

\begin{tabular}{clccc}
\hline \multirow{2}{*}{ No } & & \multirow{2}{*}{ Model } & \multicolumn{2}{c}{ Collinearity Statistic } \\
& & Tolerance & VIF \\
\hline 1 & Kepemimpinan & 0.231 & 4.338 \\
2 & Hubungan kerja & 0.239 & 4.188 \\
3 & lingkungan kerja fisik & 0.278 & 3.598 \\
\hline
\end{tabular}

Sumber: data diolah, 2018

Berdasarkan hasil pengujian heteroskedastisitas dapat dilihat bahwa hampir semua variabel memiliki nilai sig $>0,05$ ini berarti pada model regresi tidak terjadi gejala heteroskedasitisitas yang dapat dilihat pada Tabel 7 berikut.

Pengaruh tiap-tiap variabel bebas dalam model Uji Signifikansi Koefisien Regresi Secara Parsial (t-test) ini digunakan untuk mengetahui pengaruh variabel bebas, yaitu kepemimpinan $\left(\mathrm{X}_{1}\right)$, hubungan kerja $\left(\mathrm{X}_{2}\right)$, lingkungan kerja fisik $\left(\mathrm{X}_{3}\right)$ secara 
parsial terhadap disiplin kerja (Y). Uji t dilakukan dengan membandingkan nilai $t_{\text {hitung dengan }} t_{\text {tabel }}$ pada taraf signifikansi 0,05 dengan pengujian $\alpha=0,05$; $\mathrm{df}=61$, sehingga $t_{\text {tabel }}(0,05: 61)$ adalah sebesar 1,684. Hasil analisis uji $t$ dapat dilihat Tabel 8 .

Tabel 7

Hasil Uji Heteroskedastisitas (Uji Glejser)

\begin{tabular}{|c|c|c|c|c|c|c|}
\hline \multirow{2}{*}{ Model } & & \multicolumn{2}{|c|}{$\begin{array}{c}\text { Unstandardized } \\
\text { Coefficients }\end{array}$} & \multirow{2}{*}{$\begin{array}{c}\text { Standardized } \\
\text { Coefficients } \\
\text { Beta }\end{array}$} & \multirow[t]{2}{*}{$\mathrm{t}$} & \multirow[t]{2}{*}{ Sig. } \\
\hline & & $\mathrm{B}$ & Std. Error & & & \\
\hline 1 & (Constant) & .277 & .026 & & 10.764 & .000 \\
\hline 2 & Kep. & .006 & .054 & .031 & .117 & .908 \\
\hline 3 & Hub. Kerja & .054 & .053 & -.264 & -1.025 & .309 \\
\hline 4 & Lingk K. fisik & .062 & .049 & .302 & 1.263 & .211 \\
\hline
\end{tabular}

Tabel 8

Hasil Analisis Uji t-test

\begin{tabular}{cccccc}
\hline Variabel & thitung & tabel & Hasil Uji t & Hasil Hipotesis & $\begin{array}{c}\text { Tingkat } \\
\text { Signifikan }\end{array}$ \\
\hline $\mathrm{X}_{1}$ & 2,281 & 1,671 & $(2,124)>(1,671)$ & $\mathrm{H}_{0}$ ditolak & Signifikan \\
$\mathrm{X}_{2}$ & 3,368 & 1,671 & $(2,703)>(1,671)$ & $\mathrm{H}_{0}$ ditolak & Signifikan \\
$\mathrm{X}_{3}$ & 5,653 & 1,671 & $(2,156)>(1,671)$ & $\mathrm{H}_{0}$ ditolak & Signifikan \\
\hline Sumber $\cdot$ data diolah 2018 & & & &
\end{tabular}

Sumber : data diolah, 2018

Berdasarkan hasil analisis data diketahui bahwa kepemimpinan terhadap disiplin kerja karyawan berpengaruh signifikan positif. Hal ini mengandung arti bahwa semakin baik penerapan kepemimpinan yang dijalankan oleh pimpinan berakibat pada semakin tingginya kedisiplinan karyawan pada Alam Kulkul Boutique Resort. Hasil penelitian ini mendukung pernyataan Rama dan Sudharma (2013) menyatakan bahwa kepemimpinan memiliki pengaruh positif terhadap disiplin kerja karyawan, hal ini memiliki kesamaan terhadap pernyataan Mardin (2010) penerapan kepemimpian mampu membuat seluruh karyawan ikut turut serta memberikan kontribusi dan kedisiplinannya dalam melaksanakan pekerjaan. 
I Wayan Sugiantara, Pengaruh Kepemimpinan, Hubungan....

Penelitian yang dilakukan oleh (Widyastuti, 2006) membuktikan bahwa kepemimpinan memiliki keterikatan positif dalam menegakkan kedisiplinan kerja karyawan.

Hasil analisis data hubungan kerja memberikan kontribusi positif terhadap disiplin kerja karyawan, terlihat terciptanya hubungan kerja yang baik dalam perusahaan akan mampu membangkitkan kedisiplinan karyawan yang terarah pada Alam Kulkul Boutique Resort. Hasil penelitian ini searah dengan pernyataan Rejeki (2006) dimana hubungan kerja mempunyai pengaruh positif terhadap disiplin kerja karyawan. Muslim (2008) membuktikan bahwa hubungan kerja memiliki keterkaitan positif terhadap disiplin kerja karyawan. Disiplin kerja karyawan akan tercipta apabila setiap karyawan memahami hubungan yang baik terhadap sesame karyawan (Ernawati dan Ambarini, 2010).

Hasil menunjukkan lingkungan kerja fisik berpengaruh terhadap disiplin kerja karyawan, adanya prilaku yang lingkungan kerja fisik pada diri karyawan dapat mendorong untuk memberikan hasil kerja yang optimal. Mengingat hasil analisis data yang menyatakan lingkungan kerja fisik memiliki pengaruh positif terhadap disiplin kerja karyawan Alam Kulkul Boutique Resort. Semakin baik lingkungan kerja fisik pada perusahaan berakibat pada semakin tingginya disiplin kerja karyawan. Berdasarkan hasil ini mendukung penelitian Dewi (2010) memberikan hasil lingkungan kerja fisik memiliki pengaruh positif dengan disiplin kerja karyawan. Rizki (2009) menyebutkan bahwa lingkungan kerja fisik mempunyai ikatan positif dengan disiplin kerja karyawan. Rejeki (2006) lingkungan kerja fisik memiliki pengaruh yang signifikan positif terhadap disiplin 
kerja karyawan. Melalui hasil analisa regresi dan analisis Standardized Coefficients Beta variabel bebas yang berpengaruh dominan terhadap disiplin kerja karyawan pada Alam Kulkul Boutique Resort adalah lingkungan kerja fisik

\section{SIMPULAN DAN SARAN}

Berdasarkan pada pembahasan pada bab-bab sebelumnya, maka adapun halhal yang dapat disimpulkan bahwa kepemimpinan, hubungan kerja dan lingkungan kerja fisik secara parsial berpengaruh positif dan signifikan terhadap disiplin kerja karyawan pada Alam Kulkul Boutique Resort. Lingkungan kerja fisik berpengaruh dominan terhadap disiplin kerja karyawan pada Alam Kulkul Boutique Resort.

Berdasarkan simpulan, saran-saran yang dapat diberikan kepada manajemen Hendaknya pimpinan perusahan tetap memperhatikan aspek lingkungan fisik di perusahaan, sebagai variabel yang dominan berpengaruh terhadap disiplin kerja karyawan dengan menciptakan lingkungan yang kondusif melalui pengaturan suhu udara dalam ruang kerja agar meningkatkan kedisiplinan karyawan dalam bekerja. Aspek kepemimpinan harus menjadi acuan bagi pemimpin perusahaan. Sikap tegas, tepat da bertanggung jawab harus dimiliki pemimpin dalam menjalankan sikap kepemimpinan di dalam perusahaan. Hubungan kerja yang sudah terbina baik saat ini agar terus di pupuk di benak karyawan, sehingga mampu bekerja sama dalam melaksanakan pekerjaan.

\section{REFERENSI}

Apfia Ferawati. (2017). Pengaruh Lingkungan Kerja Terhadap Disiplin Karyawan. Jurnal Agora, 5(1), 1-3. 
Bangun Prajadi Cipto Utomo. (2014). Pengaruh Kepemimpinan, Motivasi Kerja, Disiplin Kerja dan Lingkungan Kerja terhadap Kinerja Karyawan dan Dosen STMIK Duta Bangsa Surakarta. Jurnal Sainstech Politeknik Indonusa Surakarta, 1(1), 13-24.

Deni Susanti. (2012). Pengaruh Efektifitas Kepemimpinan Terhadap Disiplin Kerja Pegawai Dinas Perhubungan, Komunikasi dan Informatika Kabupaten Tulungagung. Jurnal Otonomi, 12(1), 75-83.

Dewi Andriani. (2010). Pengaruh Lingkungan Kerja Terhadap Disiplin Kerja Karyawan PT. Hassco Multi Kimindo Sidiarjo. Jurnal Aplikasi Manajemen, 8(4), 971-983.

Ernawati dan Ambarini. (2010). Pengaruh Hubungan Kerja Dan Lingkungan Kerja Terhadap Kinerja Pegawai Dengan Motivasi Kerja Sebagai Variabel Moderating. Jurnal Ekonomi dan Kewirausahaan, 10(2), 100-112.

Fazriyas dan Elwamendri. (2010). Analisis Tata Hubungan Kerja Pengelolaan Areals Eks HPH Dalam Kesatuan Pengelolaan Hutan (KPH) di Provinsi Jambi. Jurnal Ekonomi Bisnis, 2(1), 1-13.

Fransiska Guantina Lumban Raja. (2016). Hubungan Motivasi, Lingkungan Kerja, Kepemimpinan terhadap Disiplin Kerja Karyawan PT. Asiana Technologies Lestary Jakarta. Jurnal Psyche, 1(2), 1-12.

Ghozali, Imam. (2007). Aplikasi Analisis Multivariate dengan Program SPSS. Universitas Diponogoro.

Gouzali Saydam. (2007). Manajemen Sumber Daya Manusia. Jakarta: PT. Gunung Agung.

Handoko, T. Hani. (2007). Manajemen Personalia dan Sumber Daya Manusia. Edisi 2. Yogyakarta: BPFE.

Hasibuan. (2007). Manajemen Sumber Daya Manusia Dasar dari Kunci Keberhasilan. Jakarta: CV. Haji Masagung.

Jhon Nasyaroeka. (2011). Pengaruh Gaya Kepemimpinan terhadap Disiplin kerja Karyawan PT Bentoel Prima Bandar Lampung. Jurnal Organisasi Manajemen, 1(1), 9-16.

Manulang, M. (2006). Manajemen Personalia. Jakarta: Aksara Baru.

Mantra, Ida Bagus. (2008). Autobiografi Seorang Budayawan. Penyunting I.B. Wiana. Denpasar: Upada Sastra. 
Mardin Idris. (2010). Hubungan Pemahaman Kepemimpinan Islam Terhadap Disiplin Kerja Pegawai Perguruan Tinggi Islam Swasta di Yogyakarta. Jurnal Ekonomi dan Kewirausahaan, 1(2), 163-173.

Marie Elizabeth Smi. (2010). The Role of School Discipline In Comba Ting Violence In Schools In The East London Region. Internasional Journal of fort hace London, 1(4), 101-127.

Martoyo, Susilo. (2007). Manajemen Sumber Daya Manusia. Cetakan kel Yogykarta: BPFE.

Muhaimin. (2004). Hubungan Antara Kepuasan Kerja Dengan Disiplin Kerja Karyawan Operator Shawing Computer Bagian Produksi Pada PT Primarindo Asia Infrastruktur Tbk Di Bandung. Jurnal Ekonomi dan Bisnis, 1(1), 1-11.

Nitisemito, Alex S. (2007). Manajemen Personalia. Edisi Ketiga. Jakarta: Ghalia Indonesia.

Nola Fitria Sutrisno. (2008). Hubungan antara persepsi terhadap beban kerja dengan disiplin kerja pada pegawai Negeri sipil bagian kepegawaian dan keuangan Setda Bogor. Jurnal Kajian Bisnis, 1(4), 6-19

Rejeki Pardede. (2006). Analisis Faktor-faktor yang mempengaruhi Disiplin Kerja KaryawanBagian Personalia pada PT. (Persero) Pelabuhan Indonesia I Medan. Jurnal Ekonomi dan Kewirausahaan, 2(4), 215-228.

Rifka Setyowati, Linda Lambey, dan Farlane Rumokoy. (2017). The Effect of Leadership, Work Environment, And Discipline on Employees Productivity at PT. Amri Margatama Capital. Jurnal EMBA, 5(3), 4515-4524.

Rizki Suheri. (2009). Pengaruh lingkungan kerja dan kepuasan kerja terhadap disiplin kerja karyawan pada Dinas Sosial Kabupaten Padang Pariaman. Skripsi. Universitas Andalas

Stephen. (2013). The Impact of Employee-involved Physical Workplace on SelfDisciplinary Behavior in the China context. International Journal DSIAPDSI Conference, 1(1), 1-22

Sugiyono. (2013). Metode Penelitian Administrasi. Bandung: CV. Alfabeta.

Tohardi, Ahmad. (2008). Pemahaman Praktis Manajemen Sumber Daya Manusia. Pontianak: Mandar Maju. 
I Wayan Sugiantara, Pengaruh Kepemimpinan, Hubungan....

Tony Murphy. (2004). Discipline Procedures For The Metropolitan Fire And Emergency Services Board (MFESB). Internasional Journal of leadership, 1(1), 1-35.

Valensia Angelina Wisti Dapu. (2015). The Influence of Work Discipline, Leadership, and Motivation on Employee Performance at PT. Trakindo Utama Manado. Jurnal EMBA, 3(3), 352-361.

Wibowo. (2007). Faktor-faktor Yang Berpengaruh Terhadap Disiplin Kerja Pegawai Pada PT Amidharma Surabaya. Skripsi. Universitas Surabaya.

Widyastuti Pratiwiningsih. (2006). Pengaruh Faktor-faktor kepuasan kerja terhadap Disiplin kerja pegawai lembaga pemasyarakatan kelas IIB di Klaten. Jurnal Kewirausahaan, 4(1), 12-29. 